UNIVERSITY OF CALIFORNIA PUBLICATIONS

IN

AGRICULTURAL SCIENCES

Vol. 1, No. 2, pp. 21.37

October 15,1912

\title{
STUDIES ON THE PHENOLDISULPHONIC
}

ACID METHOD FOR DETERMINING

\section{NITRATES IN SOILS}

$\mathrm{BY}$

C. B. LIPMAN and L. T. SHARP

UNIVERSITY OF CALIFORNIA PRESS

BERKELEY 


\section{UNIVERSITY OF CALIFORNIA PUBLICATIONS}

Note-The University of California Publications are offered in exchange for the publi. cations of learned societies and institutions, universities and libraries Complete lists of all the publications of the University will be sent upon request. For sample copies, lists of publications and other information, address the Manager of the University Press, Berkeley, Callfornia, U. S. A. All matter sent in exchange should be addressed to The Exchange Department, University Iibrary, Berkeley, California, U. S. A.

\section{OTTO HARRASSOWITZ} IEIPZIG

Agent for the series in American Archaeology and Ethnology, Classical Philology, Education, Modern Philology, Philosophy, Psychology.

\section{R. FRIEDI AENDFR \& SOHN BFRIIN}

Agent for the series in American Arch aeology and Fthnology, Agricultural Sc1ences, Botany, Geology, Mathematics, Path ology, Physiology, Zoology, and Memoirs.

AGRICUITURAT SCIFNCES.-Charles B. Iipman, Ernest B, Babcock, and Leroy Ander. son, Editors. Price per volume, \$3.50.

V01. 1. 1. The Distribution and Activities of Bacteria in Solls of the Arid Region, by Charles B. Lipman. Pp. 1-21. October, 1912 $\$ 0.20$

2. Studies on the Phemoldisulphonic Acid Method for Determining Nitrates in Soils, by C. B. Lipman and I. T. Sharp. Pp. 23-37. October, 1912. .15

AGRIOUITURE-The Publications of the Agricultural Experiment Station consist of Bulletins and Biennial Reports, edited by Professor Thomas Forsyth Hunt Director of the Station. These are sent gratis to citizens of the State of California. For detailed information regarding them address The Agricultural Experiment Station, Berkeley, California.

BOTANY. W. A. Setchell, Editor. Price per volume, \$3.50. Volumes I (pp, 418), II (pp. 360), III (pp. 400), completed. Volumes IV and $V$ in progress.

Vol. 1. 1. A Botanical Survey of San Jacinto Mountains, by Harvey Monroe Hall. Pp. 1-140; plates 114. June, 1902

2. Two new Ascomycetous Fungi Parasitic on Marine Algae, by Minnie Reed. Pp. 141-164; plates 15-16. November, 1902

3. Algae of Northwestern America, by William Albert Setchell and Nathaniel Iy on Gardner. Pp. 165-418; plates 17-27. March, 1903

Vol. 2. 1. A Review of Californian Polemoniaceae, by Jessie Milliken. Pp. 1 71; plates 1-11. May, 1904

2. Contributions to Cytological Technique, by W. J. V. Osterhout. Pp. $73-90 ; 5$ text-figures. June, 1904

3. Iimu, by William Albert Setchell. Pp. 91-113. April, 1905

4. Post-Embryonal Stages of the Iaminariacoae, by William Albert Setchell. Pp, 115-138; plates 13-14. April, 1905

5. Regeneration among Kelps, by William Albert Setchell. Pp. 139-168; plates 15-17. July, 1905

6. A New Genus of Ascomycetous Fungi, by Nathaniel Iyon Gardner. Pp. 169-180; plate 18. July, 1905

7. Teratology in the Flowers of some California Willows, by William Warner Mott. Pp. 181-226; plates 16-20. December, 1905

8, 9, 10, 11. (In one cover.) The Resistance of Certain Marine Algae to Changes in Osmotic Pressure and Temperature. The Role of Osmotic Pressure in Marine Plants. On the Importance of Physiolog. ically Balanced Solutions for Plants. The Antitoxin Action of Potassium on Magnesium. By W. J. V. Osterhout. Pp. 227-236. March, 1806

12. Oytological Studies in Cyanophyceae, by Nathaniel Lyon Gardner. Pp. 237-296; plates 21-26. November, 1906

13. On a Small Collection of Mosses from Alaska, by J. Cardot and $T$. Thériot. Pp. 297-308; plates 27-28. December, 1906

14. Some Unreported Alaska Sphagna, together with a Summary of the Cryptogamic Work of the University of Califormia Botanical BXpedition to Alaska in 1899, by William Albert Setcholl. Pp. 309. 315. September, 1907

15. On Nutrient and Balanced Solutions, by W. J. V. Osterhout. Pp. 317. 318. October, 1907

16. A Synopsis of the North American Godetias, by Willis Iinn Jepson. Pp. 319-354; plate 29. December, 1907 Index, pp. $355-860$ 
UNIVERSITY OF CALIFORNIA PUBLICATIONS

IN

AGRICULTURAL SCIENCES

Vol. 1, No. 2, pp. 21-37

October 15,1912

\section{STUDIES ON THE PHENOLDISULPHONIC \\ ACID METHOD FOR DETERMINING \\ NITRATES IN SOILS}

BY

C. B. LIPMAN AND L. T. SHARP

Despite the fact that some careful research has been carried out on the colorimetric method for determining nitrates, many factors concerned with it have not been studied, and the somewhat uncertain nature of the method makes it imperative to control, so far as possible, every factor which may interfere with the accurate analysis of nitrate-containing material. These statements apply particularly to the analysis of soils for nitrates and the authors therefore deem the subjoined data, derived from a thorough investigation, deserving of the attention of every soil chemist.

Among the interfering factors in the phenoldisulphonic acid method which have been either studied inadequately or not at all, are the effects of salts, the effects of agents employed to precipitate the clay and organic matter, and the effects of decolorizing agents. Cognizance must be taken of all of these factors by the chemist in the determination of nitrates and in the arrangement and interpretation of results. The importance of salt effects and their significance in this connection are emphasized by the fact that many soils, and particularly those of arid and semiarid regions, may frequently be found to a greater or less degree impregnated with one or more of the so-called "alkali salts," together with which, it often happens indeed, consider- 
able quantities of nitrates are to be found. So far as the claycoagulating substances are concerned, it has always been a common practice in soil work to employ varying amounts of a saturated solution of alum to obtain a clear soil solution, and more recently it has been proposed by investigators who have studied the method under discussion to use aluminum eream for the purpose in place of alum. For decolorizing solutions both aluminum cream and bone black have been used. The methods for both clay coagulation and decolorization are obviously essential in most soil work, since ordinary filtration, without the use of such agents, can rarely be depended on to yield a clear, colorless soil solution, even if time be no object. The employment of the Pasteur Chamberland filter to remove clay has been found by direct investigation to involve well-defined losses of nitrates.

It is not our purpose here to enter into a lengthy review of other investigations bearing on the subject in hand, but into a brief discussion of the more important ones which show the questions still remaining unsolved or bring out certain results with which ours do not agree.

In $1894 \mathrm{Gill}^{1}$ carried out a series of painstaking investigations which, briefly, indicate (1) that for purposes of accuracy the phenoldisulphonic acid employed in the nitrate determination must be carefully prepared to insure a uniform compound for use as a standard; (2) that chlorine induces losses of nitric acid both when the solution containing nitrate is evaporated on the water bath and when the residue is treated with the reagent; (3) that $\mathrm{Na}_{2} \mathrm{CO}_{3}$ added to the nitrate-containing solution to prevent escape of nitric acid during evaporation induces losses of nitrates varying in quantity from four to six per cent; (4) that alumina may be used to precipitate colloidal material for obtaining a clear solution; (5) that silver sulphate, if free from nitrate, may be employed to precipitate chlorine, thus removing an important interfering agent.

More recently Chamot and his coworkers ${ }^{2}$ have prosecuted an even more thoroughgoing investigation than the preceding, in which the most emphasis has been placed, however, on the mode of preparation of the tripotassium salt of nitrophenoldisulphonic

\footnotetext{
1 Jour. Am. Chem. Soc. vol, 16, p. 122. 1894.
} 
acid used as the reagent. Their results indicate (1) that in order to obtain the phenoldisulphonic acid free from the mono and tri-phenolsulphonic acid a careful digestion of the phenol and sulphuric acid under certain constant conditions must be assured; (2) that the mono and tri-phenolsulphonic acids introduce other colors which interfere with the readings in the colorimeter; (3) that the tri-potassium salt of nitrophenoldisulphonic acid gives the characteristic color employed in the determination and should always be used as a standard; (4) that heating the dry residue of nitrates even for several hours on the water bath occasions no losses; (5) that aluminum cream is the best precipitating agent for organic matter of several used and occasions no losses of nitrates; (6) that 2 e.c. of the phenoldisulphonic acid should be used in uniform amounts in all determinations; (7) that $\mathrm{KOH}$ was to be preferred to $\mathrm{NaOH}$ and $\mathrm{NH}_{4} \mathrm{OH}$, as the alkali employed; (8) that chlorides induced losses of nitrates; (9) that carbonates and organic matter did likewise; (10) that temperature, concentration, and length of exposure to reagent greatly affect results; and (11) that there have been other minor effects of iron, magnesium, and nitrites.

Reference must also be made here to the brief investigation of Stewart and Greaves ${ }^{3}$ pertaining to the effect of chlorine in determining nitrates in soils, both because the work is recent and because it is the only one published which is derived from researches on soils. This investigation and those above reviewed cover most completely the questions involved and reference will be made in the diseussion of our experimental work below to those questionable points which were considered settled but which our work shows were far from being so.

\section{The Interference of Salts with the Nitrate Determination}

As has been above indicated the salt accumulations which occur in the soils of California, Nevada, Utah, and other arid or semi-arid regions frequently contain considerable quantities of nitrates and the determination of the latter in the presence of the "alkali salts" is, as has been found, frequently attended

2 Ibid., vols. 21 , p. 922 ; 32 , p. $630 ; 33$, p. 366

3 Ibid., vol. 32 , p. 756 . 
with losses of nitric acid. While all the investigations above reviewed have pointed out the interference of chlorine and chlorides with the nitrate determination, and while some of them have also considered the losses occurring through the use of $\mathrm{Na}_{2} \mathrm{CO}_{3}$, no mention is made of the effects of the most common and widely spread of the alkali salts, $\mathrm{Na}_{2} \mathrm{SO}_{4}$, or Glauber salt. It seems further to have been taken for granted that $\mathrm{Na}_{2} \mathrm{CO}_{3}$ and $\mathrm{Na}_{2} \mathrm{SO}_{4}$ should, for obvious reasons, have the same effects on the nitrate determination by the phenoldisulphonic acid method. Our results do not, however, bear out this opinion. Under this head were also studied the effects of the kation as well as the anion of salts on the same determination.

Varying quantities of the salts tested were here added to the same amounts of nitrates in solution, and uniform quantities of salts were also tested as to their effects on varying quantities of nitrates. Everyone of the following tables gives the effects of one of the salts tested in accordance with the scheme above indicated and in some cases also shows how the nitrate determination is affected by varying the quantities of both the nitrates and other salts. The residue containing the salts and the nitrates was treated with 2 c.c of phenoldisulphonic acid thoroughly stirred for about two or three minutes, 25 c.c. of nitrate-free distilled water was added, and then strong ammonia drop by drop until the odor of ammonia persisted and the color was permanent. The solution was then diluted as necessary and compared in the Sargent-Kennicott colorimeter with a standard solution similarly and always freshly prepared, whose strength was in every case carefully tested. The results of these experiments are given in the following tables. 
TABLE I

EFFECTS OF $\mathrm{NaCl}$

Uniform quantities

$\mathrm{KNO}_{3}$-varying

amounts $\mathrm{NaCl}$

\section{Varying quantities}

$\mathrm{KNO}_{3}$-uniform

amounts $\mathrm{NaCl}$

Varying quantities of
both $\mathrm{KNO}_{3}$ and $\mathrm{NaCl}$

$$
\text { both } \mathrm{KNO}_{3} \text { and } \mathrm{NaCl}
$$$$
\text { Uniform amounts } \mathrm{KNO}_{3}
$$$$
\text { small amounts } \mathrm{NaCl}
$$

Color blanks

on both salts

\begin{tabular}{|c|c|c|}
\hline $\begin{array}{c}\mathrm{NaCl} \text { added } \\
\text { mgs. } \\
.25\end{array}$ & $\begin{array}{l}\text { N. added as } \\
\text { nitrate } \mathrm{mgs} \text {. } \\
.050\end{array}$ & $\begin{array}{c}\mathrm{N} \text {. found as } \\
\text { nitrate mgs. } \\
.045\end{array}$ \\
\hline .50 & .050 & .041 \\
\hline 1.00 & .050 & .035 \\
\hline 2.50 & .050 & .026 \\
\hline 1.00 & .050 & .038 \\
\hline 1.00 & .100 & .070 \\
\hline 1.00 & .250 & .215 \\
\hline 1.00 & .500 & .460 \\
\hline 1.00 & 1.000 & .940 \\
\hline 1.00 & 2.500 & 2.300 \\
\hline .25 & .050 & .046 \\
\hline .50 & .100 & .078 \\
\hline 1.00 & .250 & .230 \\
\hline 1.50 & .500 & .460 \\
\hline 2.00 & 1.000 & .900 \\
\hline 2.50 & 2.500 & 2.300 \\
\hline .01 & .050 & .051 \\
\hline .05 & .050 & .051 \\
\hline .10 & .050 & .049 \\
\hline .00 & .050 & .050 \\
\hline 2.50 & .000 & .000 \\
\hline
\end{tabular}

\section{TABLE II}

EFFECTS of $\mathrm{Na}_{2} \mathrm{SO}_{4}$

$\begin{array}{lrcc} & \text { mgs. } & \text { nitrate mgs. } & \text { nitrate mgs. } \\ \text { Amounts of nitrate } & 1.000 & .0500 & .0480 \\ \text { uniform and sulfate } & 5.000 & .0500 & .0420 \\ \text { varying } & 10.000 & .0500 & .0400 \\ & 20.000 & .0500 & .0280 \\ & 30.000 & .0500 & .0270 \\ \text { Amounts of sulfate } & 15.000 & .1500 & .1420 \\ \text { uniform and nitrate } & 15.000 & .5000 & .4950 \\ \text { varying } & 15.000 & 1.0000 & .9000 \\ & 15.000 & 2.0000 & 1.9500 \\ & 15.000 & 3.0000 & 2.8500 \\ \text { Amounts of both salts } & 1.000 & .1500 & .1420 \\ \text { varying } & 5.000 & .5000 & .4800 \\ & 10.000 & 1.0000 & .9200 \\ & 20.000 & 2.0000 & 1.9300\end{array}$


TABLE III

$\begin{array}{lccc} & \text { EFFECTS } & & \\ & \begin{array}{c}\mathrm{Na}_{2} \mathrm{CO}_{3} \text { added } \\ \text { mgs. }\end{array} & \begin{array}{c}\mathrm{N} \text {. added as } \\ \text { nitrate } \mathrm{mgs} .\end{array} & \begin{array}{c}\mathrm{N} \text {. found as } \\ \text { nitrate mgs. }\end{array} \\ \text { Amounts of nitrate } & 1.00 & .1000 & .0995 \\ \text { uniform and carbonate } & 2.50 & .1000 & .1040 \\ \text { varying } & 5.00 & .1000 & .1010 \\ & 10.00 & .1000 & .1010 \\ & 20.00 & .1000 & .1020 \\ \text { Amounts of carbonate } & 30.00 & .1000 & .1020 \\ \text { uniform and nitrate } & 10.00 & .1000 & .1000 \\ \text { varying } & 10.00 & .2000 & .2100 \\ & 10.00 & .5000 & .5000 \\ \text { Amounts of both salts } & 10.00 & 1.5000 & 1.4900 \\ \text { varying } & 1.00 & .1000 & .1010 \\ & 5.00 & .2000 & .1970 \\ & 10.00 & .5000 & .5050 \\ & 20.00 & .5000 & .5100 \\ & 30.00 & 1.5000 & 1.4900\end{array}$

The results set forth in tables I, II, and III leave no room for doubt as to the effects of "alkali" salts on the nitrate determination by the colorimetric method. Both $\mathrm{NaCl}$ and $\mathrm{Na}_{2} \mathrm{SO}_{4}$ induce large losses of nitrate, and especially is this true of $\mathrm{NaCl}$, which may be responsible for losses equivalent to forty-five per cent and more of the total nitrate present as indicated in Table I. While $\mathrm{Na}_{2} \mathrm{SO}_{4}$ induces smaller absolute losses than $\mathrm{NaCl}$, they are none the less marked, and where large amounts of the sulfate are present very considerable losses of nitrate occur.

Perhaps the most striking feature of the foregoing results is what appeals to one at first sight as the singular difference in the behavior of $\mathrm{Na}_{2} \mathrm{SO}_{4}$ and $\mathrm{Na}_{2} \mathrm{CO}_{3}$. Whereas the former is always responsible for losses in the determination of nitrates, the latter is the only one of the salts tested which has no effect and the presence of which in a long series of tests has never, except in one case, decreased the amount of nitrate present as shown by the colorimeter readings. It was naturally assumed that $\mathrm{Na}_{2} \mathrm{CO}_{3}$, after the addition of the phenoldisulphonic acid, would be converted in the presence of an excess of sulphuric acid into $\mathrm{Na}_{2} \mathrm{SO}_{4}$ and should therefore show the same decreases in the nitrate content as the latter salt. To clear up these rather puzzling facts, as above given, we decided to run a special series of experiments based on a suspicion which we had as to the 
nature of the action of the salts in question. The results of these experiments, which will be given below, make entirely clear what seemed at first quite puzzling.

In further general discussion of the tables above given, it must be added that the decreases in the nitrate content of the solutions tested as induced by the presence of salts never occurred in accordance with any definite law, the losses at times being greater with smaller amounts of salts than with larger amounts, the amounts of nitrates being constant. On the other hand, with a given amount of nitrates not exceeding one-tenth of a milligram the salts seemed always to induce larger percentage losses than they did in the case of the larger amounts of nitrates. Our results not only give good opportunity for a comparison of the effects of varying quantities of salts on the same nitrate content, but point out all the relationships between the salts and nitrates where first the former, then the latter, and finally both, are varied. There are two other points, also, which they would not seem to confirm; indeed they give entirely different evidence on these than was obtained by other investigators. The first is that small amounts of $\mathrm{NaCl}$ do not induce losses of nitrates, as claimed by Stewart and Greaves, and Table I indicates that amounts of $\mathrm{NaCl}$ below .1 milligram do not occasion any losses. The other point of difference between our results and those of the others mentioned is that $\mathrm{Na}_{2} \mathrm{CO}_{3}$ does not decrease the amounts of nitrates, no matter to what extent it is used, as shown in Table III. This is in entire disagreement with the results of Gill and Chamot and his coworkers, who claimed that $\mathrm{Na}_{2} \mathrm{CO}_{3}$ and other carbonates induced losses of nitrates, in the determination outlined. It must also be added here that the effects of $\mathrm{Na}_{2} \mathrm{SO}_{4}$ as given in Table II constitute the first published results, so far as we are aware, on the effects of Glauber salt on the nitrate determination, and they have indeed been indirectly responsible for the discovery of one or two other points of interest which will be discussed below.

The results above given indicate the effects of each of the salts taken singly on the nitrate determination. To make the data more complete it was thought desirable to test various mixtures of the same salts and note their effects. Table IV gives the results obtained. 
TABLE IV

Effects of Mixed Alkali Salts

\begin{tabular}{|c|c|c|c|c|}
\hline $\begin{array}{c}\mathrm{Na}_{2} \mathrm{C}_{3} \mathrm{O}_{3} \\
\text { mgs. }\end{array}$ & $\begin{array}{c}\mathrm{Na}_{2} \mathrm{SO}_{4} \\
\text { mgs. }\end{array}$ & $\begin{array}{r}\mathrm{NaCl} \\
\mathrm{mgs} .\end{array}$ & $\begin{array}{l}\text { N. added as } \\
\text { nitrate mgs. }\end{array}$ & $\begin{array}{l}\mathrm{N} \text {. found as } \\
\text { nitrate mgs }\end{array}$ \\
\hline 1 & 1 & 1 & .1000 & .055 \\
\hline 5 & 5 & 5 & .1000 & .026 \\
\hline 10 & 10 & 10 & .1000 & .021 \\
\hline 20 & 20 & 20 & .1000 & .017 \\
\hline 1 & 1 & $\ldots .$. & .1000 & .082 \\
\hline 5 & 5 & $\ldots$. & .1000 & .081 \\
\hline 10 & 10 & .... & .1000 & .075 \\
\hline 20 & 20 & $\ldots$ & .1000 & .077 \\
\hline 1 & $\ldots .$. & 1 & .1000 & .061 \\
\hline 5 & $\ldots$ & 5 & .1000 & .060 \\
\hline 10 & .... & 10 & .1000 & .055 \\
\hline 20 & .... & 20 & .1000 & .028 \\
\hline .... & 1 & $i$ & .1000 & .050 \\
\hline$\ldots$. & 5 & 5 & .1000 & .042 \\
\hline .... & 10 & 10 & .1000 & .033 \\
\hline$\ldots$ & 20 & 20 & .1000 & .030 \\
\hline 10 & 10 & 10 & 2000 & .086 \\
\hline 10 & 10 & 10 & .5000 & .125 \\
\hline 10 & 10 & 10 & 1.000 & .360 \\
\hline 10 & 10 & 10 & 2.000 & 1.140 \\
\hline
\end{tabular}

The same marked losses in nitrates occur here as where the salts are employed singly. $\mathrm{NaCl}$ seems to be responsible again for the greatest losses, $\mathrm{Na}_{2} \mathrm{SO}_{4}$ is next in order, and $\mathrm{Na}_{2} \mathrm{CO}_{3}$ seems to have little or no effect. Since these salts occur together in alkali soils, however, the results in Table IV possess considerable significance and interest, especially since they point out what enormous losses of nitrates occur where such large amounts as ten milligrams of each of the salts are added to the nitrate-containing solution.

The Interference of Precipitants of Clay and Organic

\section{Matter on the Nitrate Determination}

It is very singular that analytical chemists have for so long a time been employing such materials as saturated alum solutions, aluminum cream, and bone black for precipitating clay and organic matter in obtaining the soil solution to be used for nitrate determinations without ever having attempted to ascer- 
tain if such materials in any way affect the accuracy of the determination. Indeed Chamot and his coworkers have recommended the use of aluminum eream for removing suspended material from the solution, and claim to have had very satisfactory results in the use of that material. Our experiments in this series were intended to clear up this question and the following results show very strikingly that none of the materials mentioned may be employed in the nitrate determinations without incurring very serious losses. Table $\mathrm{V}$ gives results obtained in the use of potash alum, and Table VI gives results obtained in the use of bone black and aluminum cream.

\section{TABLE V}

EFFECTS OF $\mathrm{K}_{2} \mathrm{Al}_{2}\left(\mathrm{SO}_{4}\right)_{4}$

Amounts of nitrate

$\begin{array}{ccc}\mathrm{K}_{2} \mathrm{Al}_{2}\left(\mathrm{SO}_{4}\right)_{4} & \mathrm{~N} \text {. added as } & \mathrm{N} \text {. found as } \\ \text { added } & \text { nitrate } & \text { nitrate }\end{array}$ uniform and alum

5.00

mgs.

varying

12.50

.050

.040

25.00 .

.036

50.00

.033

100.00

.031

150.00

.034

.040

Amounts of alum uniform

.050

.050

.050

.050

.035

45.00

.050

.035 and nitrate varying

Amounts of both 
TABLE VI

Effects of Aluminum Cream and Bone Black

$\begin{array}{lcc}\text { Sufficient aluminum cream to } & \begin{array}{c}\text { N. added as } \\ \text { nitrate } \\ \text { mgs. }\end{array} & \begin{array}{c}\text { N. found as } \\ \text { nitrate } \\ \text { mgs. }\end{array} \\ \text { clear solution. Five minutes } & .5000 & .254 \\ \text { exposure } & 1.000 & .648 \\ \text { Twice the amount of aluminum } & 2.000 & 1.460 \\ \text { cream used above. Exposed one } & .5000 & .100 \\ \text { and one-half hours } & 1.0000 & .300 \\ \text { Sufficient bone black to clear } & 2.0000 & 1.180 \\ \text { and decolorize solution } & 1.0000 & .135 \\ & 2.5000 & .650 \\ \end{array}$

The data in Tables V and VI are clearly very striking. The enormous losses of nitrates sustained through the use of a saturated solution of alum, varying quantities of aluminum cream and bone black, make these substances entirely unfit for use as precipitants for clay, or organic matter, or both, when nitrates are to be determined. While bone black occasions the largest losses, and potash alum the smallest, of any of the substances above described, the losses of nitrates brought about through the use of all the precipitants are too great to permit of their continuance in a method for nitrate determinations which is none too accurate under the best of conditions. It is therefore evident that nitrates are lost not merely through the loss of nitric acid, as is the case where salts are used, but that there is a loss of nitrates mechanically through adsorption on the part of the colloidal material of the precipitant, as must be the case where such substances as aluminum eream and bone black are used. The large amounts of colloids possessed by these substances, with the accompanying large surface areas, evidently prevent some of the nitrate in solution from going through the filter.

On casting about for a method to precipitate clay or organic matter, we first tried the Briggs filter pump, but found that open to two objections. First, the losses of nitrates through what we look upon as adsorption on the part of the clay filter, though not very large, were nearly equal to those induced by small amounts of sulfates. Second, while the filter pump yields a clear solution, it does not serve to decolorize solutions. After several fur- 
ther attempts to find a coagulating and decolorizing agent which might promise well for this method, it struck us that quicklime, being the best coagulating material for clay, might perhaps also serve to remove organic matter and yet might not decrease seriously the amount of nitrates in the solution to be tested. Accordingly, tests were carried out by adding lime to solutions containing known amounts of nitrates, to soils containing known amounts of nitrates and to soils with unknown amounts of nitrates, in which latter a comparison was also especially made between lime and aluminum cream. We found in these experiments that the losses of nitrate through the use of lime were not only very small or negligible, but that the action of lime in precipitating both clay and organic matter was equal to or better than that of the best of the coagulating and decolorizing agents. Its coagulating action on elay has of course always been recognized in soil physies. The results of the experiments are given in Table VII.

\section{TABLE VII}

EFfects of Lime

A-Solutions of known nitrate content

$\begin{array}{ccc}\begin{array}{c}\text { CaO present } \\ \text { grms. }\end{array} & \begin{array}{c}\text { N. added as nitrate } \\ \text { mgs. }\end{array} & \begin{array}{c}\text { N. found as nitrate } \\ \text { mgs. }\end{array} \\ 1 & 1.0000 & 1.0150 \\ 3 & 1.0000 & .9800 \\ 5 & 1.0000 & .9550 \\ 3 & 5.0000 & 4.6500\end{array}$

B-Soils of known nitrate content

$\mathrm{CaO}$ present $\mathrm{N}$. present as nitrate $\mathrm{N}$. found as nitrate

Lime ground with

soil and water

Lime added to muddy suspension

2

3.280

3.150

$2 \quad 3.280$

3.200

C-Comparison of lime and aluminum cream on soil of unknown nitrate content

Lime ground with soil and water

C'aO present
grms.

Lime added to muddy suspensiori

Sufficient aluminum cream added to clear solution
$N$. found as nitrate mgs.

1.210

1.225 .800 
It would seem from these results therefore that lime can yield a clear, colorless solution without decreasing the quantity of nitrates present in the solution appreciably, and that it is therefore the only one of the coagulating agents above tested which can be safely used in the work. We commend it to soil chemists and others making nitrogen determination under similar conditions. Only where very large quantities of lime are employed, and they are not necessary, have we found definite losses of nitrates. We find that 2 grams of $\mathrm{CaO}$ is sufficient to coagulate the clay in 100 grams of loam soil and to remove whatever color may be present at the same time.

While lime has been used by some chemists in accordance with the method above outlined, its use has by no means been general and no data prior to this existed with reference to its effects on the nitrate determination. J. G. Lipman and P. E. Brown give directions in their laboratory manual on Soil Bacteriology for the use of 2 grams of lime to precipitate the clay in the 100 gram samples of soil used in nitrification experiments, but we have never seen any published statements beyond that as to the advisability or feasibility of employing lime. It is certainly surprising that those who have tested the method for nitrate determination should not have tried and urged the use of lime as a substitute for alum or aluminum eream.

\section{Other Experiments on Salt Effects}

It appeared interesting, when the results in Tables I, II, and III were obtained, to ascertain if the kation as well as the anion of salts was responsible for losses of nitrates. Accordingly a series of experiments was instituted in which the effects of $\mathrm{NaCl}, \mathrm{KCl}$, and $\mathrm{MgCl}_{2}$ could be compared. The following results were obtained. 
TABLE VIII

EFFECTS OF IONS

\begin{tabular}{|c|c|c|c|c|}
\hline $\begin{array}{l}\mathrm{KCl} \\
\mathrm{mgs} \text {. }\end{array}$ & $\begin{array}{c}\mathrm{MgCl}_{2} \\
\mathrm{mgs} .\end{array}$ & $\begin{array}{l}\mathrm{NaCl} \\
\text { mgs. }\end{array}$ & $\begin{array}{l}\text { N. added as } \\
\text { nitrate } \\
\text { mgs. }\end{array}$ & $\begin{array}{l}\text { N. found as } \\
\text { nitrate } \\
\text { mgs. }\end{array}$ \\
\hline 1 & $\cdots$. & $\ldots$. & .1000 & .070 \\
\hline 5 & .... & $\ldots$. & .1000 & .063 \\
\hline 10 & .... & .... & .1000 & .055 \\
\hline 20 & .... & .... & .1000 & .050 \\
\hline ... & 1 & .... & .1000 & .057 \\
\hline$\ldots$. & 5 & $\ldots$. & .1000 & .028 \\
\hline .... & 10 & … & .1000 & .016 \\
\hline$\ldots$. & 20 & $\cdots$ & .1000 & .011 \\
\hline$\ldots$. & .... & 1 & .1000 & .065 \\
\hline$\ldots$. & $\ldots$. & 5 & .1000 & .043 \\
\hline$\ldots .$. & $\ldots$. & 10 & .1000 & .035 \\
\hline .... & $\ldots$ & 20 & .1000 & .038 \\
\hline
\end{tabular}

It is evident from Table VIII that the chlorine and not the base is the interfering element, and while the amounts of chlorine were not so proportioned as to be equivalent in the case of the two monovalent bases, the effect is clearly seen of the smallest and the largest amounts of chlorine present in the salts, which can be calculated from the molecular weights. The negative ion therefore seems to be the active agent in setting free nitric acid, but the decreases, depending as they do on other conditions such as evaporation on the water bath and length of exposure, do not take place in aceordance with any definite law.

The last phase of the salt effects studied was that above referred to in the discussion of Tables I, II, and III, namely, the reason for differences in the action of $\mathrm{Na}_{2} \mathrm{CO}_{3}$ and $\mathrm{Na}_{2} \mathrm{SO}_{4}$ on nitrate-containing material. Since it was evident that $\mathrm{Na}_{2} \mathrm{CO}_{3}$ should react similarly to $\mathrm{Na}_{2} \mathrm{SO}_{4}$ when the phenoldisulphonic acid was added to the dried residue to be analyzed, we suspected that the losses occurring when $\mathrm{Na}_{2} \mathrm{SO}_{4}$ was employed came about on the water bath in evaporating the solution, under which conditions only, according to our work, could there have been a difference in the action of the two salts.

The results given in the following table prove that our suspicions were well founded. In this series the dry salts were thoroughly mixed with the nitrate-containing residue obtained by evaporating standard nitrate solutions, and then the phenoldisulphonic acid reagent was added. $\mathrm{NaCl}$ was similarly tested. 
TABLE IX

Effects of Dry Mixing of Nitrates and Salts

$\begin{array}{ccccc}\mathrm{Na}_{2} \mathrm{CO}_{3} & \begin{array}{c}\mathrm{NaCl} \\ \mathrm{mgs}\end{array} & \begin{array}{c}\text { N. added as } \\ \text { mgs. } \\ \text { nitrate } \\ \text { mgs. }\end{array} & \begin{array}{c}\text { N. found as } \\ \text { nitrate } \\ \text { mgs. }\end{array} \\ 50 & \ldots . . & \ldots . & .1000 & .097 \\ 100 & \ldots . . & \ldots . & .1000 & .102 \\ \ldots . & 50 & \ldots .- & .1000 & .103 \\ \ldots . & 100 & \ldots . & .1000 & .102 \\ \ldots . & \ldots . & 50 & .1000 & .080 \\ \ldots . & \ldots . & 100 & .1000 & .062\end{array}$

The data in Table IX make it quite clear that the losses due to $\mathrm{Na}_{2} \mathrm{SO}_{4}$ occur only when the latter salt is present in solution with nitrates and the solution is evaporated on the steam bath. When, however, the salt is mixed dry with the dry nitrate no losses of the latter occur any more than they do when $\mathrm{Na}_{2} \mathrm{CO}_{3}$ is added. The same is not true, however, of $\mathrm{NaCl}$, as is shown in the last table. That salt causes losses of nitrates during both the evaporation on the steam bath and the reaction setting chlorine free in the treatment of the dry residue with phenoldisulphonic acid. This latter fact is a confirmation of work done by Gill and reviewed above. We have thus shown the individual reaction of each of the salts as related to the nitrate determination and the causes which are responsible for the difference. Nitric acid is evidently set free from nitrates through the combined action of heat and the $\mathrm{SO}_{4}$ radicle on the steam bath and in the evolution of chlorine when the phenoldisulphonic acid is added to nitrate and chloride-containing material. $\mathrm{Na}_{2} \mathrm{CO}_{3}$, however, possessing only a weak and unstable acid radicle is powerless to set free nitric acid either through the help of heat on the steam bath or by its reaction with the phenoldisulphonie acid.

\section{General Remarks}

So many factors may interfere with the determination of nitrates by the phenoldisulphonie acid method that it would appear to be almost worthless, and yet it would seem to us that since there is no other good method to take its place which is nearly as simple and capable of use in very numerous determinations, it is worth while taking certain precautions to avoid 
error, and to establish the method on a firmer basis. Our results as above outlined show that losses of nitrates are induced by the presence of $\mathrm{NaCl}$ and $\mathrm{Na}_{2} \mathrm{SO}_{4}$, and such losses are indeed hard to avoid when working with "alkali soils." Even the suggestion of Chamot that $\mathrm{AgSO}_{4}$ might be used to precipitate chlorides would seem, from our results, not to be useful, since the addition of sulfate to the solution would accomplish very considerable losses itself, even if the silver sulfate can be obtained nitrate-free, which Chamot claims is seldom the case. So that while we deem it unsafe in the presence of considerable quantities of salts containing chlorides and sulfates to determine nitrates by the phenoldisulphonic acid method and would therefore recommend the Street modification of the Ulsch method in such eases, it is likewise clear that many of the nitrate determinations made in soil laboratories, as is especially the case in soil bacteriological work, would not be interfered with by salts. In such cases the method can be safely depended on if potash alum, aluminum cream, and bone black are not used to coagulate clay and organic matter, since they have been found in the researches above described to be productive of very serious errors. We recommend as a substitute for these coagulating agents the oxide of lime in its chemically pure state, to be employed in accordance with the method above given. The losses of nitrates sustained through its use have been shown to be very small in the work above reported, and it may be employed by grinding the soil with water or by direct addition to the muddy suspension prepared from the soil.

Other sources of loss such as those brought about through the sterilization of controls in the autoclave are unavoidable. They have been found at times to be distinctly appreciable, and especially in the presence of considerable quantities of organic matter. It is further of the greatest interest to learn, from the experiments above described, of the action of the anion of the salts employed in our studies and the losses of nitrates occurring on the water bath from solutions being evaporated there when either $\mathrm{NaCl}$ or $\mathrm{Na}_{2} \mathrm{SO}_{4}$ is present.

We should also make mention here of our attitude toward the use of $\mathrm{NH}_{4} \mathrm{OH}$ instead of $\mathrm{KOH}$, which was found superior 
to the former in the investigations above reviewed. While higher absolute results may no doubt be obtained from the use of $\mathrm{KOH}$ than from $\mathrm{NH}_{4} \mathrm{OH}$, and while in addition ammonia possesses other objectionable features, we were not aware of the first of these objections when these investigations were begun and did not deem the others serious enough to warrant a change in the established method. Moreover, the same relative values would exist for the data above given if obtained with one or the other of the hydrates, and therefore our results, having been obtained throughout by the use of ammonia, do not in any way lose their value. We do intend, however, in the future to employ $\mathrm{KOH}$ exclusively in nitrate determinations made in this laboratory. Finally we desire to call the attention of soil chemists to the fact that losses of nitrates by the agencies above described never seem to occur in accordance with any definite law, with the exception of the ease in which the various alkali chlorides are compared. In these it would appear, from calculations which we have made, that the losses of nitrates are proportional to the amounts of chlorine present. While no law can be formulated, however, in accordance with which nitrates are lost in the presence of salts, it may be possible to work out tables for the losses of nitrates incurred in the presence of varying quantities of chlorides and sulphates, and to make corrections, therefore, in samples whose composition is unknown after alkali determinations are made. It is true, however, that calculation has shown on the basis of data in Table VIII that the losses of nitrates induced by chlorides alone are proportional to the amount of chlorine present.

\section{CONCLUSIONS}

1. The "alkali" salts $\mathrm{NaCl}$ and $\mathrm{Na}_{2} \mathrm{SO}_{4}$ induce losses of nitrates when the latter are determined by the phenoldisulphonic acid method. $\mathrm{Na}_{2} \mathrm{CO}_{3}$ has no such effect. $\mathrm{NaCl}$ induces much greater losses than $\mathrm{Na}_{2} \mathrm{SO}_{4}$.

2. Among the substances used to coagulate clay and organic matter from solutions in which nitrates are to be determined, potash alum, aluminum cream, and bone black have been found decidedly unreliable. They all induce large losses of nitrates. 
3. Lime has been found to be much more reliable for the purpose named than any of the other substances, the losses incurred through its use being very small.

4. The reason for the difference between the action of $\mathrm{Na}_{2} \mathrm{SO}_{4}$ and $\mathrm{Na}_{2} \mathrm{CO}_{3}$ so far as the nitrate losses are concerned is to be found in the fact that $\mathrm{Na}_{2} \mathrm{SO}_{4}$ induces the loss of nitric acid from the solution while the latter is being evaporated, while $\mathrm{Na}_{2} \mathrm{CO}_{3}$ containing only a weak acid radicle has no power to set nitric acid free. Neither $\mathrm{Na}_{2} \mathrm{SO}_{4}$ nor $\mathrm{Na}_{2} \mathrm{CO}_{3}$ has the power to set nitric acid free from nitrates when the dry residues of the two are mixed prior to treatment with phenoldisulphonic acid.

5. Losses of nitrates from solutions as induced by chlorides alone seem to be proportional to the amount of chlorine present.

6. The work of Gill which showed that chlorine induces losses both on the water bath and in mixing the dry residue with phenoldisulphonic acid is confirmed. 



\section{UNIVERSITY OF CALIFORNIA PUBLICATIONS-(Continued)}

701. S. $1907-1909$.

1. Compositae of Southern California, by Harvey Moore Hall. Pp. 1. 302; plates 1-3, with a map. December, 1907

2. The Origin, Structure, and Function of the Polar Caps in Smilacina amplexicaulis Nutt, by H. D. Densmore. Pp. 303-330; plates 4-8. December, 1908

3, 4. (In one cover.) The Value of Sodium to Plants by Reason of Its Protective Action. On the Effects of Certain Poisonous Gases on Plants, By W. J, V. Osterhout. Pp. 331-340, June, 1908

5. Contributions to the Knowledge of the California Species of Crustaceous Corallines, I, by Maurice Barstow Nichols. Pp. 341-348; plate 9. December, 1908

6. Contributions to the Knowledge of the California species of Crustaceous Corallines. II, by Maurice Barstow Nichols. Pp. 349-370; plates 10-13. April, 1909

7. New Chlorophyceae from California, by Nathaniel Lyon Gardner. Pp. 371-375; plate 14. April, 1909

8. Plantae Mexicanae Purpusianae, by T. 8. Brandegee. Pp. 377-396. May, 1909 Index, pp. $397-400$.

V01. 4. 1910.

1. Studies in Omamental Trees and Shrubs, by Harvey Monroe Hall. Pp. 1-74; plates 1-11; 15 text-figures. March, 1910

2. Gracilariophlla, a New Parasite on Gracitaria confervoides, by Harriet L. Wilson. Pp. 75-84; plates 12-13. May, 1910

3. Plantae Mexicanae Purpusianae, II, by T. S. Brandegee. Pp. 85-95. May, 1910

4. Lewvenia, a New Genus of Flagellates, by N. L. Gardner. Pp. 97-106; plate 14. May, 1910

5. The Genus Sphaerosoma, by William Albert Setchell. Pp. 107-120; plate 15. May, 1910

6. Variations in Nuclear Extrusion Among the Fucaceae, by Nathaniel Iy on Gardner. Pp. 121-136; plates 16-17. August, 1910 ...............

7. The Nature of the Carpostomes in the Cystocarp of Ahnfeldtia gigarti noides, by Ada Sara McFadden. Py. 137-142; plate 18. February, 1911

8. On a Colaeodasya from Southern California, by Mabel Effie McFadden. Pp. 143-150; plate 19. February, 1911

9. Fructification of Macrocystis, by Edna Juanita Hoffman. Pp. 151-158; plate 20. February, 1911

10. Enythrophylhum delesserioides J. Ag, by Wilfred Charles Twiss. Pp. 159-176; plates 21-24. March, 1911.

11. Plantae Mexicanae Purpusianae, III, by T. S. Brandegee. Pp. 177-194. July, 1911

12. Now and Noteworthy California Plants, $I_{2}$ by Harvey Monroe Hall. Pp. 195-208. March, 1912

13. Die Hydrophyllaceen der Slerra Nevada, by August Brand. Pp. 209227. March, 1912

14. Algae Novae et Minus Cognitae, I, by William Albert Setchell. Pp. 229-268; plates 25-31. May, 1912

15. Plantae Mexicanae Purpusianae, IV, by Townshend Stith Brandegee. Pp. 269-281. June 26, 1912 


\section{UNIVERSITY OF CATIFORNIA PUBLICATIONS-(Continued)}

AMERICAN ARCHAEOLOGY AND EMHNOLOGY,A. L. Kroober, Editor, Prico per volume, $\$ 3.50$ (Volume I, \$4.25). Volumes I-IX completed. Volumes $X$ and $X I$ in progress.

GEOLOGY.-Bulletin of the Department of Geology. Andrew C. Iawson and John C. Merriam, Editors. Price per volume, \$3.50. Volumes I (pp. 428), II (pp. 450), III (pp. 475), IV (pp. 462), V (pp. 458), and VI, completed. Volume VII in progress.

ZOOLOGY.-W. F. Ritter and C. A. Kofoid, Editors. Price per volume, \$3.50. Volumes I (pp. 317), II (pp. 382), III (pp. 383), IV (pp. 400), V (pp. 440), VI (pp, 478), VII (pp. 446), and VIII (pp. 357) completed. Volumes IX, $\mathbf{X}$, and $\mathbf{X I}$ in progress. Commencing with Volume II this series contains the Contributions from the Jaboratory of the Marine Biological Association of San Diego.

MEMOIRS OF THE UNIVERSITY OF CAIIFORNIA (Quarto).

Vo1. 1. 1. Triassic Ichthyosauria, with special reference to the American Forms, by John C. Merriam. Pp. 1-196; plates 1-18; 154 text-figures. September, 1908

2. The Fauna of Rancho La Brea, Part 1, Occurrence, by John C. Merriam. Pp. 197-213; plates 19-23. Navember, 1911

Vol. 2. Silva of Califormia, by W. I. Jepson. Pp. 480 , plates 85 . December, 1910. \$9; buckram, $\$ 10$; carriage extra.

Other sexies in Classical Philology, Fconomics, Education, Fgyptian Archaeology, Engineering, Entomology, Graeco-Roman Archaeology, History, Mathematios, Psychology, Semitic Philology, Modern Philology.

UNIVERSITY OF CALIFORNIA CHRONICLE.-An official record of University life, issued quarterly, edited by a committee of the faculty. Price, $\$ 1.00$ per year. Current volume No. XIV.

ADMINISTRATIVE BULXETINS OF THE UNIVERSITY OF CATIFORNIA,-Edited by the Recorder of the Faculties. Includes the Register, the President's Report, the Secretary's Report, and other official announcements.

European agent for the series in American Archaeology and Bthnology, Classical Philology, Education, Philosophy, and Semitic Philology, Otto Harrassowitz, Lieipzig. For the series in Agricultuxal Sciences, Botany, Geology, Pathology, Physiology, Zoology, and also American Archaeology and Ethnology, R. Friedlaender \& Soln, Berlin. 